\title{
内視鏡用自動縫合器を用いる前立腺全摘除術の成績
}

\author{
1)飯田市立病院泌尿器科 \\ ${ }^{2)}$ 自治医科大学泌尿器科 \\ 山下 俊郎 ${ }^{1)}$ 村石 修2) 梅田 俊一1) 松下 高暁

\section{PRELIMINARY EXPERIENCE OF RADICAL RETROPUBIC PROSTATECTOMY USING AN ENDOSCOPIC STAPLER} \\ Toshio Yamashita ${ }^{1)}$, Osamu Muraishi ${ }^{2)}$, Shunichi Umeda ${ }^{1)}$ and Takaaki Matsushita ${ }^{1)}$ \\ ${ }^{1)}$ Urology, Iida Municipal Hospital \\ ${ }^{2)}$ Department of Urology, Jichi Medical School
}

(Purpose) Preliminary experience of radical retropubic prostatectomy using an endoscopic stapler is reported.

(Methods) An endoscopic stapler was applied for ligation and division of the lateral prostatic ligaments and the deep dorsal vein complex during radical retropubic prostatectomy in 8 patients.

(Results) Procedures with stapler were easily performed and almost always effective for hemostasis. Mean total blood loss was $663 \mathrm{ml}$, mean $575 \mathrm{ml}$ of autologous blood was given. None of patients was transfused allogeneic blood.

(Conclusion) These results indicate that an endoscopic stapler may facilitate radical retropubic prostatectomy.

Key words: prostatectomy, surgical stapling, prostatic diseases

\footnotetext{
要旨：(背景と目的)我々は内視鏡用自動縫合器を用いた膀胱全摘除術の有用性をすでに報告したが，そ の手技を前立腺全摘除術にも応用した.

（対象と方法）限局性前立腺癌 8 例に対して, 自動縫合器を用いて前立腺全摘除術を施行した。手術 は順行性摘除とし, 膀胱頝部の離断後に, 左右の前立腺側方勒帯をそれぞれ 1 から 2 回自動縫合し切離 した。また，深部陰茎背静脈叢も自動縫合器にて縫合処理した。

(結果) 総出血量は平均 $663 \pm 300 \mathrm{ml}$ で，平均 $575 \pm 328 \mathrm{ml}$ の自己血輸血を行った. 同種血輸血を必要と した例はなかった．自動縫合器に関する副作用はなかった。

（結論）自動縫合器を用いることにより，出血量の少ない前立腺全摘除術が比較的容易に行えると思 われた。

キーワード：前立腺全摘除術，自動縫合器，前立腺癌
}

\section{緒 言}

膀胱癌および前立腺癌の根治手術において，深部陰 茎背静脈叢 (dorsal vein complex，以下 DVC と略す) の止血が重要で，種々の手技が開発されてきたが，特 にバンチング法が有名である ${ }^{1)}$. 本邦では村石が内視 鏡手術用の自動縫合器をDVCの縫合に用いる手技を 開発し ${ }^{233)}$, 我々の施設でも1994年から膀胱全摘除術に 応用してきた. 膀胱全摘除術の際, 多数の血管からな る膀胱および前立腺側方鞀帯も, DVC 同様その処理を
誤ると相当の出血をみることがある．そのため，DVC のみならず膀胱および前立腺側方勒帯の縫合処理にも 自動縫合器を応用するようにしたところ，従来の術式 に比し, 有意に出血量が少なく, より短時間で膀胱全 摘除術が可能となった ${ }^{4)}$. 我々は, 1996年より前立腺全 摘除術も膀胱全摘除術同様に自動縫合器を用いて行っ ており，その手技はすでに概説されている3. 本論文で は，未だ症例数は少ないが，同一術者による本手術手 技の手術成績を報告する。 


\section{対象および方法}

対象は1996年 3 月から1997年 9 月までに限局性前立 腺癌（臨床病期 B-C）にて根治手術を予定した 8 例. 年齢は54歳から69歳までで平均62.5歳. 全例診断確定 後 $3 \sim 4$ 力月間 LH-RH アナログ製剤と抗男性ホルモ ン製凨によるいわゆる neo-adjuvant 療法を施行し, 前 立腺特異抗原が正常化してから手術を行った。 1 例以 外400から $800 \mathrm{ml}$ の術前自己血貯血を行った。

使用機器は United States Surgical 社製, Multifire Endo GIA 30-3.5 (図 1 ) を用いた. この自動縫合器 を用いると 3 列のチタニウム製ステープルが $3 \mathrm{~cm}$ に 渡り一対打針され，その間の組織が内蔵されたナイフ にて切開される.内視鏡手術用の自動縫合器のため, 操作スペースの狭い骨盤腔内でも容易に操作できる.

手術は順行性摘除 ${ }^{5)}$ とした。まず膀胱頸部を離断し, 精囊周囲を十分に剥離する．デノビエ腔を十分に剥離 し、デノビエ腔に挿入した指で前立腺側方䩲帯を挟ん で確認する．この後に自動縫合器で前立腺側方靶帯を 挟み, 縫合切離する(図 2 ). 勃起神経を温存する場合

図 1 使用する内視鏡用自動縫合器 矢印：カートリッジ

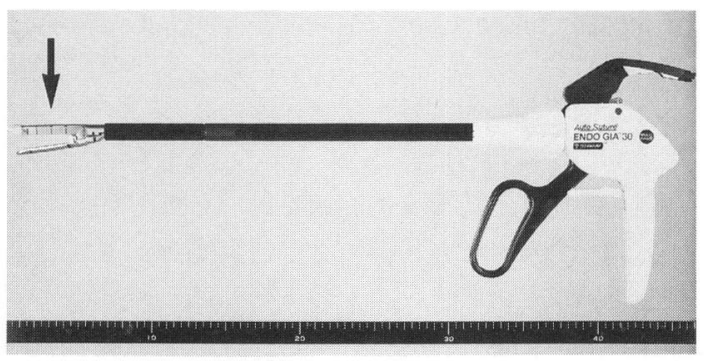

は, 前立腺筋膜を切開し5), 神経血管束を含む組織を直 腸側に圧排してから，なるべく腹側で前立腺側方勒帯 を自動縫合した，前立腺の大きさにより異なるが，片 側 1 から 2 回自動縫合器を使用した. 前立腺尖部の側 方勒帯がわずかに残るが, 曲鈿子で挟んで切離した後, 針系にて縫合する.内骨盤筋膜を切開し, 用手的に DVC を肛門挙筋から剥離する。恥骨前立腺靱帯は切開 せずに，恥骨前立腺鞀帯とDVCを一括して直鉗子で 挟んで圧挫してから, 自動縫合器を用いて縫合切開す る(図 3 )。尿道を挟まないように，かつ，十分に DVC が縫合されるように, 自動縫合器の先端をいわゆる三 角部間隙5ににってくるようにする，尿道の腹側部の 組織がわずかに切開されずに残るが，剪刀にて追加切 開し前立腺を摘除する．以上述べた DVC の処理に関 しては，すでに報告した方法におおむね準じている が2) 4), 使用機器が異なっている.すなわち, 既報では ナイフが内蔵されておらず 3 列のステープルで組織を 縫合する機能のみを持った Multifire Endo TA 30一-3.5を使用していた. 同機器にて DVC を縫合した 後に,3列のステープルの最も前立腺側のステープルラ インと前立腺被膜の間を電気メスにて切開して尿道背 面に到達する手技である。 今回述べた手技では DVC の自動縫合と同時に切開も行われる点が異なってい る. より迅速に DVC の処理ができ, かつ, 前立腺被膜 に切り込む恐れがない手技である。

\section{結果}

自動縫合器の使用は 1 例目より容易に施行でき, 全 例でほぼ満足ゆく止血ができた．ステープルラインの 一部から若干出血することがあったが, 電気凝固ある いは Z 縫合で容易に止血できた。総出血量は200から

図 2 自動縫合器による前立腺側方䩲带の処理.

$\mathrm{A}$ ：膀胱頸部離断後の状態. B : 自動縫合器で左前立腺側方䩲帯を挟んだ状態. C : 前 立腺側方靱帯の縫合切離後の状態.

A

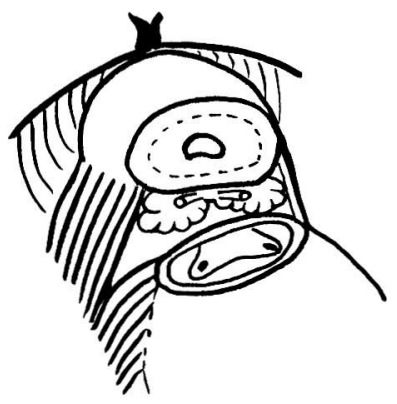

B

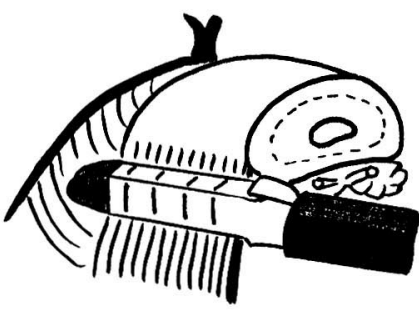

C

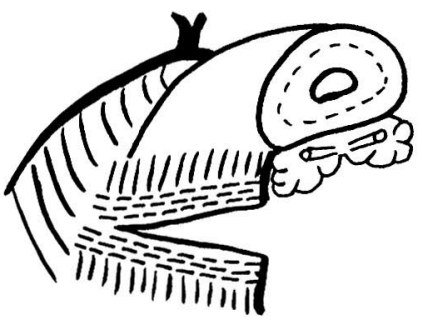


図 3 自動縫合器によるDVCの処理.

A：内骨盤筋膜の切開後の状態. 矢印：DVC, 小矢印：恥骨前立腺勒帯. B：自動縫合 器で恥骨前立腺靯帯と DVC を一括して挟んだ状態. C : DVCの縫合処理後の状態. 矢 印：縫合されたDVC

A

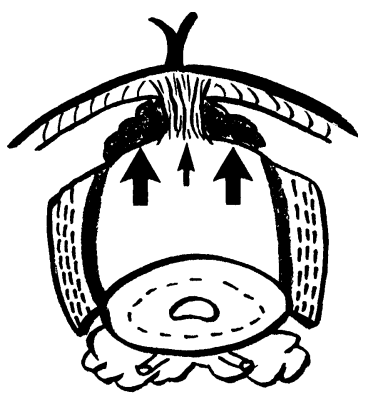

B

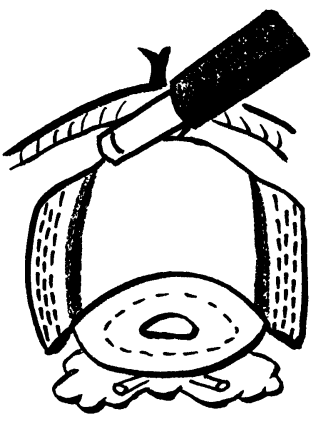

C

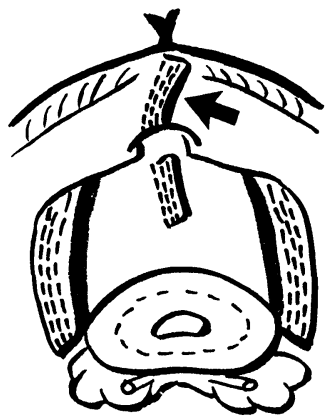

$1,000 \mathrm{ml}$, 平均 $663 \pm 300 \mathrm{ml}$ であった. 総手術時間は 177 から214分, 平均199分士13分であった. 0 から $800 \mathrm{ml}$, 平均 $575 \pm 328 \mathrm{ml}$ の自己血輸血を行った. 同種血輸血を 必要とした例はなかった。

8 例中 6 例で完全に尿禁制が得られ, 術後平均約 4 カ月でパッド不要となった。これに対して 2 例で， 1 日 1 〜 枚のパッドを要する軽度の腹圧性尿失禁が術 後 1 年以上続いている.

8 例中 3 例で片側の, 1 例で両側の勃起神経温存手 術を施行した. 全例で何らかの術後内分泌療法を施行 しているため, まだ, 結論は出ないが, 両側の神経温 存を行った 1 例で術後 8 力月の時点で勃起能が確認さ れた。

\section{考察}

Gould $ら^{6}$ は逆行性前立腺全摘除術における自動縫 合器の使用経験を報告しており, 平均出血量は約 400 $\mathrm{ml}$ であった. 我々の成績は彼等の成績より劣るもので あったが, その理由は我々の経験症例が少なかったた めかも知れない。しかし, 我々の経験では前立腺側方 鞅帯とDVCの処理に際して, 大出血を来したことは なく,縫合線の一部から小出血が時に見られるのみで, 電気凝固あるいは $Z$ 縫合によって容易に止血できた。 従って自動縫合器による止血は大変信頼できるものと 確信している. Gould ら ${ }^{6}$ と我々の経験から, 逆行性・ 順行性どちらの摘除法でも自動縫合器を用いることに より, 容易により出血の少ない手術が可能であると考 える.

前立腺全摘除術の対象となる症例は通常比較的若く
全身状態が良いので, 術前に自己血を貯血する良い適 応と思われる は手術前に十分に時間があり，貯血には都合が良い. 我々の症例でも原則として $800 \mathrm{ml}$ の自己血を用意して 手術に臨み，全例で同種血輸血を回避できた。自動縫 合器により出血量をコンスタントに少なくできたため と思われた。

我々の平均総手術時間は199分と決して短くはない かもしれないが, 新しい術式であるためほぼ全例でビ デオ撮影を行いつつ手術したことも勘案されねばなら ない.

前立腺全摘除術の術後の問題として勃起不全がある が, 勃起神経温存術は自動縫合器を用いる術式でも可 能であると報告されている ${ }^{6)}$. 神経血管束の近傍を自 動縫合器にて処理すると, 電気メスの使用を少なくで きるため，むしろ，通常の手術手技より神経温存には 良いとの見解もある ${ }^{6)}$. 自験例からも今後の経過観察 が必要であるが，神経温存術への応用の可能性が示唆 された。

尿禁制に関しては本邦の報告と大差なかった ${ }^{8)}$. 我々は前立腺全摘除術を集学的治療の一部と考え, 術 後に放射線治療を施行することが多いが，その事を考 慮すればほぼ満足すべき成績と考えた。

自動縫合器に起因する副作用をこれまで全く経験し ていないが, 今後, ステープルが膀胱尿道吻合部から 尿路へ迷入し結石形成をきたすことがあるかもしれな いので経過観察が必要と考えている4).

本術式の最も大きな問題は, 使用機器が比較的高価 
で, かつ, 保険診療でその費用がまかなえないことで あろう。本邦の一般病院では前立腺全摘除術はいまだ 頻度の高い手術とはいいがたく，年に数回ある程度の 施設が多いと推測される。症例数の少ない中で, 通常 の技術を修得し, そして, 維持することはなかなか困 難であろう。一方, 自動縫合器を用いる術式は比較的 容易に修得できる方法と思われ，例え費用がかかって も出血の少ない手術がコンスタントにできることは意 義あることではないかと考えた。

本論文の要旨は第85回日本泌尿器科学会総会 (於横浜市) にて発表した。

\section{文献}

1) Myers, R.P.: Improving the exposure of the prostate in radical retropubic prostatectomy: Longitudinal bunching of the deep venous plexus. J. Urol., 142, 1282-1284, 1989.

2) Muraishi, O., Yamashita, T. and Tokue, A.: A simplified technique for securing the dorsal vein complex. Br. J. Urol., 80, 336-337, 1997.

3）村石 修, 山下俊郎, 西澤秀治：自動縫合器を用い
る膀胱・前立腺摘除術. 臨泌, 50, 1047-1053, 1996.

4) Yamashita, T., Muraishi, O, Umeda, S. and Matsushita, T.: Radical cystectomy using endoscopic stapling devices: Preliminary experience with a simple and reliable technique. J. Urol., 157, 263-265, 1997.

5）岡田清己, 清滝修二, 北島清彰：神経保存前立腺全 摘術. 臨泌，40，791-795， 1986.

6) Gould, D.L. and Borer, J.: Applied stapling technique in radical retropubic prostatectomy: Efficient, effective and efficacious. J. Urol., 155, 1008-1010, 1996.

7）根橋勝義, 笠原高太郎, 秋山昌範, 住吉義光 : 前立 腺全摘除術に対する自己血貯血の経験. 西日泌尿, 58, 984-986, 1996.

8）荒川創一, 原 勲, 三宅秀明, 田口 功, 山田裕 二, 後藤章暢, 上野康一, 松井 隆, 藤澤正人, 江 藤 弘, 郷司和男, 岡田 弘, 守殿貞夫: 限局性前 立腺癌に対する前立腺全摘除術の検討. 泌尿紀要, 42, 811-815, 1996.

(1998年3月23日受付，7月7日受理） 